\title{
THE ROLE OF SPERMINE IN THE INHIBITION OF STAPHYLOCOCCUS AUREUS BY HUMAN SEMEN
}

BY

\author{
J. GUREVITCH, R. ROZANSKY, D. WEBER, A. BRZEZINSKKY, \\ AND B. ECKERLING
}

From the Departments of Clinical Bacteriology and Obstetrics and Gynaecology of the Hebrew University, Hadassah Medical School, Jerusalem, Israel

(RECEIVED FOR PUBLICATION FEBRUARY 2, 1951)

The inhibitory activity of human semen on the growth of Staphylococcus aureus has been reported previously (Rozansky, Gurevitch, Brzezinsky, and Eckerling, 1949).

\section{The Function of Human Semen}

The investigation has now been extended using 12 addiiional freshly isolated strains of Staph. aureus.

Materials and Methods.- Seventy-five specimens of semen from 53 patients (of the male sterility clinic) between the ages of 23 and 51 years were examined. Six of these were azoospermic, 25 oligospermic (less than 60 million spermatozoa per $\mathrm{ml}$.), and 22 were normospermic. Ten specimens of human blood serum, 10 of cerebrospinal fluids, 10 of fluids from ovarian cysts, eight of amniotic fluids, four of pleural exudate, three of tears, and three of ox semen* were also tested in a similar manner. Materials were only taken from patients who had not received antibiotic treatment. The specimens of human semen were kept at room temperature for four hours before examination, then tested immediately, or after 72 hours at $8^{\circ} \mathrm{C}$. or 14 days' refrigeration at $8^{\circ} \mathrm{C}$. Twelve specimens were also examined after heating at $90^{\circ} \mathrm{C}$. for 30 minutes. In addition to the three strains of Staph. aureus used in the previous study, 12 freshly isolated strains from surgical cases or pyogenic skin infections were tested. All strains were actively haemolytic, coagulase-positive, and mannitol-positive. The method described in the previous study (Rozansky et al., 1949) was used. On plates inoculated with the test strain of Staph. aureus, six cups with an external diameter of $8 \mathrm{~mm}$. were placed. Each cup received one or two drops of the fluid to be tested, the plates were incubated overnight at $37^{\circ} \mathrm{C}$., and the zone of inhibition measured. Wherever possible, two examinations

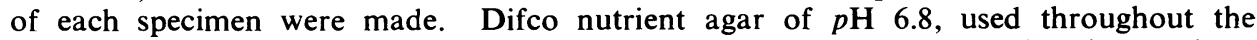
previous experiments, was employed at the beginning of this series, but it was later found that a slightly alkaline medium gave better results. The remaining tests were performed on agar plates of $p \mathrm{H} \mathrm{7.4.}$

Results.-As may be seen from Table I, of the 41 specimens of semen examined, 37 inhibited the growth of the Heatley strain of Staph. aureus over an area 10-25 mm. in diameter. Of these 37 specimens, 14 were normospermic, 21 oligospermic, and two azoospermic. Nineteen of these specimens were tested in duplicate and similar

* Obtained by courtesy of Dr. Y. Flesh, Jerusalem, and Mr. R. Mentzel, Israel Cattle Breeders` Association centre for artificial insemination, Kinereth. 
TABLE I

INHIBITION OF THE Growth of Staphylococcus aureus (Heatley Strain) By HuMAN SEMEN

\begin{tabular}{|c|c|c|c|c|c|}
\hline & & & No. of Specimens Tested & Positive & Negative \\
\hline $\begin{array}{l}\text { Normospermic } \\
\text { Oligospermic } \\
\text { Azoospermic }\end{array}$ & $\begin{array}{l}. \\
\cdots \\
\cdots\end{array}$ & $\begin{array}{l}\cdots \\
\cdots \\
\cdots\end{array}$ & $\begin{array}{r}17 \\
21 \\
3\end{array}$ & $\begin{array}{r}14 \\
21 \\
2\end{array}$ & $\begin{array}{l}3 \\
0 \\
1\end{array}$ \\
\hline \multicolumn{3}{|c|}{ Total } & 41 & 37 & 4 \\
\hline
\end{tabular}

Semen tested after 4 hours' storage at room temperature.

Positive $=$ Area of inhibition 10-25 mm. in diameter.

Negative $=$ No inhibition.

areas of inhibition were found on both plates. Four specimens (three normospermic and one azoospermic) showed no area of inhibition when first examined, i.e., four hours after the collection of the material, but one of these retested after 72 hours produced an area of inhibition $13 \mathrm{~mm}$. diameter on two plates. The other three specimens could not be examined a second time. Seven specimens heated for 30 minutes at $90^{\circ} \mathrm{C}$. all retained their inhibitory effect on the growth of Staph. aureus.

Table II summarizes the results obtained with 21 specimens after 72 hours' cold storage. Twelve specimens were of the series already tested four hours after collection, and nine were tested for the first time after 72 hours' storage. Of the 21 specimens, 20 (eight normospermic, ten oligospermic, and two azoospermic) gave positive results, 15 of them tested in duplicate, and six on one plate only. Four of these specimens were heated at $90^{\circ} \mathrm{C}$. for half an hour. The results showed no change in their inhibitory activity.

TABLE II

Semen Tested after 72 Hours' Storage at $8^{\circ} \mathrm{C}$.

\begin{tabular}{lll|c|c|c}
\hline & & & No. of Specimens Tested & Positive & Negative \\
\hline Normospermic & $\ldots$ & $\ldots$ & 9 & 8 & 1 \\
Oligospermic & $\ldots$ & $\ldots$ & 10 & 10 & 0 \\
Azoospermic &. & $\ldots$ & 2 & 2 & 0 \\
\hline & Total & $\ldots$ & 21 & 20 & 1 \\
\hline
\end{tabular}

Table III summarizes the results with 12 specimens after 14 days' storage in the refrigerator. Eight specimens (three normospermic, three oligospermic, and two azoospermic) were found to be positive, and four (one normospermic and three oligospermic) negative. Three of the specimens giving negative results had been positive when initially examined four hours after the collection of the specimens.

Table IV shows the results of the inhibitory effect of human semen on 14 different strains of Staph. aureus. One hundred and twenty-four tests were made with 75 specimens of semen. Strains No. 598 and No. 924, examined at the beginning of the present study, were tested with agar plates of $p \mathrm{H} 6.8$ which may account for the greater number of negative results obtained. 
TABLE III

Semen Tested after 14 Days' Storage at $8^{\circ} \mathrm{C}$.

\begin{tabular}{lll|c|c|c}
\hline & & & No. of Specimens Tested & Positive & Negative \\
\hline Normospermic &. & $\ldots$ & 4 & 3 & 1 \\
Oligospermic &. & $\ldots$ & 6 & 3 & 3 \\
Azoospermic &. & $\ldots$ & 2 & 2 & 0 \\
\hline & Total &.. & 12 & 8 & 4 \\
\hline
\end{tabular}

TABLE IV

Inhibitory Efficacy of Human Semen on 14 Freshly Isolated Strains of Staphylococcus aureus

\begin{tabular}{c|c|c|c|c}
\hline $\begin{array}{c}\text { Staph. aureus } \\
\text { Strain }\end{array}$ & $\begin{array}{c}\text { No. of Specimens } \\
\text { Tested }\end{array}$ & Positive & Negative & Media \\
\hline 598 & 9 & 5 & 4 & $p \mathbf{H} 6 \cdot 8$ \\
924 & 7 & 4 & 3 &,,, \\
\hline 1498 & 6 & 5 & 1 & $p \mathbf{H ~} 7 \cdot 4$ \\
1605 & 7 & 5 & 2 & \\
1705 & 1 & 1 & 0 & \\
1718 & 3 & 0 & \\
2191 & 14 & 3 & 0 & \\
2196 & 3 & 2 & 0 & \\
2315 & 2 & 6 & 0 & \\
2528 & 6 & 4 & 1 & \\
2200 & 5 & 4 & 0 & \\
750 & 4 & 3 & 0 & \\
\hline 314 & 4 & 63 & 1 & \\
\hline Totals & 14 & & 12 & \\
\hline
\end{tabular}

Positive $=$ Area of inhibition $12-25 \mathrm{~mm}$.

Negative $=$ No inhibition.

Starting with Staph. aureus strain No. 1498, agar plates of $p \mathrm{H} 7.4$ were used, and on alkalinized agar 54 specimens were positive and only five gave negative results, with areas of inhibition of the freshly isolated strains similar to those obtained with the Heatley strain. The three specimens, after cold storage for 21 days, tested with Staph. aureus No. 1718, gave positive results. From these results it is obvious that freshly isolated strains of Staph. aureus are as readily inhibited as the Heatley strain which has been used in our laboratory for several years.

\section{Discussion}

As the inhibitory effect of semen on the growth of Staph. aureus was observed both in normospermia and azoospermia, the active principle cannot be related to the presence of spermatozoa but is contained in the fluid portion of the semen. That the active principle is thermostable was shown by 12 specimens of semen 
which, after being kept at $90^{\circ} \mathrm{C}$. for half an hour, were tested with one or more strains of Staph. aureus ; all retained their inhibitory activity.

Three specimens of ox semen were tested using four strains of Staph. aureus. Twelve examinations were performed, all of which gave negative results. Since the $p \mathrm{H}$ of ox semen is 6.6-6.8, four additional tests were made after alkalinization to a $p \mathrm{H}$ of 7.6-8.0 in order to approximate it to the $p \mathrm{H}$ of human semen. However, these alkalinized ox semen specimens also gave negative results.

Serum, tears, amniotic fluid, cerebrospinal fluid, pleural exudate, and fluid from an ovarian cyst were tested in a similar manner and did not show any signs of inhibitory activity. Four specimens of semen were tested against Esch. coli, Salm. paratyphi A, Ps. pyocyanea, and Bact. alkalescens, and, as previously reported, showed no evidence of inhibition.

\section{The Hypothetical Function of Spermine and Spermidine}

In view of the thermostability of the growth-inhibitory agent it was concluded that this agent was not a protein. It was assumed that the poly-amines, spermine and spermidine, found in human semen might be responsible for the inhibition of bacterial growth. Inhibition of the growth of Staph. aureus by spermine was observed by Bichowsky-Slomnitzki (1948). Synthetic spermine tetrahydrochloride and spermine phosphate extracted from human semen were therefore tested for their inhibitory effect on the growth of Staph. aureus.

Materials and Methods.-Spermine tetra iydrochloride (La Roche) was dissolved in distilled water in dilutions varying from $12.5 \mathrm{mg} \%$ to $200 \mathrm{mg} \%$. Spermine phosphate was extracted from pooled human semen, according to the method described by Harrison (1933). Each of three pooled samples, obtained from $20 \mathrm{ml}$. of semen, yielded about $5 \mathrm{mg}$. of crystalline spermine phosphate. Since spermine phosphate is readily soluble in slightly alkaline solutions (Guggenheim, 1940), a $200 \mathrm{mg} . \%$ solution was made in distilled water by adding n/100 NaOH till $p \mathrm{H} 7.4$ was reached.

The inhibitory activity of spermine tetrahydrochloride was tested on the Heatley strain and five freshly isolated strains of Staph. aureus, and spermine phosphate was tested on the Heatley strain and three of these other strains. All the strains were actively haemolytic, coagulase-positive, and mannitol-positive.

The method used was that described above, using Difco nutrient agar of $p \mathrm{H} 6.8$ and the same agar alkalinized to $p \mathrm{H} 7.4$ by adding a few drops of $\mathrm{n} / 10 \mathrm{NaOH}$.

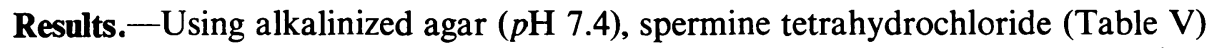
in a concentration of $200 \mathrm{mg} . \%$ inhibited the bacteria in all the tests. A concentration of $100 \mathrm{mg} . \%$ inhibited the growth in 43 of 44 tests, and a concentration of $50 \mathrm{mg} . \%$ inhibited the growth in 24 of 27 tests. Using a concentration of $25 \mathrm{mg} . \%$, it inhibited 17 of 22 tests, but with a concentration of $12.5 \mathrm{mg} \%$ it inhibited only

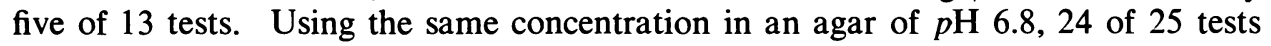
were negative and only one test, with a concentration of $100 \mathrm{mg} \%$ spermine tetrahydrochloride, was positive.

Three specimens of spermine phosphate extracted from pooled human semen were similarly tested (Table VI). Twelve tests using a concentration of $200 \mathrm{mg} . \%$, and nine tests with a concentration of $100 \mathrm{mg} . \%$ on agar of $p \mathrm{H} \cdot 7.4$ all gave positive results, the area of inhibition being 11-18 mm. in diameter. With agar of $p \mathrm{H} \mathrm{6.8,} \mathrm{of} \mathrm{eight}$ 
TABLE V

INHIBITION OF Six Strains of Staph. aureus By SPERMine Tetrahydrochloride (LA ROCHE)

\begin{tabular}{c|c|c|c|c|c|c}
\hline & \multicolumn{3}{|c|}{ Medium $p \mathrm{H} 7 \cdot 4$} & \multicolumn{3}{c}{ Medium $p \mathrm{H} 6.8$} \\
\cline { 2 - 7 } $\begin{array}{c}\text { Concentration } \\
\text { (mg. \%) }\end{array}$ & $\begin{array}{c}\text { No. of } \\
\text { Tests }\end{array}$ & Positive & Negative & $\begin{array}{c}\text { No. of } \\
\text { Tests }\end{array}$ & Positive & Negative \\
\hline 200 & 10 & 10 & 0 & 4 & 0 & 4 \\
100 & 44 & 43 & 1 & 8 & 1 & 7 \\
50 & 27 & 24 & 3 & 7 & 0 & 7 \\
25 & 22 & 17 & 5 & 4 & 0 & 4 \\
$12 \cdot 5$ & 13 & 5 & 8 & 2 & 0 & 2 \\
\hline
\end{tabular}

Positive test $=$ Area of inhibition 11-18 mm. in diameter. Negative test $=$ No inhibition.

examinations, six were positive (area of inhibition $10-14 \mathrm{~mm}$. in diameter), and only two negative.

\section{Discussion}

The inhibitory activity of spermine tetrahydrochloride is influenced by the $p \mathrm{H}$ of the agar. Only very high concentrations of spermine tetrahydrochloride were able to inhibit the growth on agar of $p \mathbf{H} 6.8$. A concentration of $1,000 \mathrm{mg} . \%$ of spermine tetrahydrochloride was tested twice, an area of inhibition up to $22 \mathrm{~mm}$.

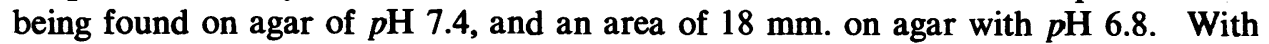
extracted spermine phosphate, the effect of the $p \mathrm{H}$ of the medium was not as striking and the results obtained resembled the findings with human semen, where greater areas of inhibition were obtained on alkaline agar of $p \mathrm{H} 7.4$ than on agar of

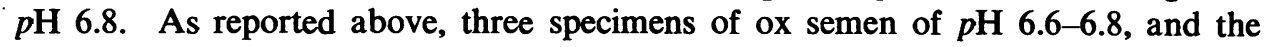
same specimens alkalinized to $p \mathrm{H} 7.6$ and 8.0, had no inhibitory effect on the growth of Staph. aureus. Since ox semen does not contain spermine (Guggenheim, 1940 ; Harrison, 1931) this furnishes additional evidence of the role of spermine in inhibiting the growth of Staph. aureus by semen. The concentrations of spermine tetrachloride and spermine phosphate used in our experiments were within the range of the spermine phosphate concentrations found in human semen, i.e., $60-250 \mathrm{mg} . \%$ (Guggenheim, 1940; Harrison, 1933). The results of the present study seem to warrant the conclusion that spermine is the principle active in the inhibition of bacterial growth by human semen plasma.

The role of spermidine, the second poly-amine present in human semen, has not yet been examined.

Spermine tetrahydrochloride, spermine phosphate, and plasma of human semen showed no inhibitory activity when tests were performed with Bacto stock culture agar $(p H$ 7.5).*

* A medium of a more complete nature than our standard medium. Apparently one or more of its components counteract the antibacterial effect of spermine. 
TABLE VI

Inhibition of Four Strains of Staph. aureus by Three Specimens of Spermine Phosphate Extracted from Pooled Human Semen

\begin{tabular}{|c|c|c|c|c|c|c|}
\hline \multirow[b]{2}{*}{$\begin{array}{l}\text { Concentration } \\
(\mathrm{mg} . \%)\end{array}$} & \multicolumn{3}{|c|}{ Medium $p \mathrm{H} \quad 7.4$} & \multicolumn{3}{|c|}{ Medium $p \mathbf{H ~ 6 . 8}$} \\
\hline & $\begin{array}{l}\text { No. of } \\
\text { Tests }\end{array}$ & Positive & Negative & $\begin{array}{l}\text { No. of } \\
\text { Tests }\end{array}$ & Positive & Negative \\
\hline $\begin{array}{l}200 \\
100\end{array}$ & $\begin{array}{r}12 \\
9\end{array}$ & $\begin{array}{r}12 \\
9\end{array}$ & $\begin{array}{l}0 \\
0\end{array}$ & $\begin{array}{l}5 \\
3\end{array}$ & $\begin{array}{l}4 \\
2\end{array}$ & $\begin{array}{l}1 \\
1\end{array}$ \\
\hline
\end{tabular}

Positive test $=$ Area of inhibition $11-18 \mathrm{~mm}$. in diameter.

Negative test $=$ No inhibition.

Positive test $=$ Area of inhibition $10-14$ $\mathrm{mm}$. in diameter.

Negative test $=$ No inhibition.

Summary

Human semen, synthetic spermine tetrahydrochloride, and spermine phosphate extracted from human semen have been examined for their inhibitory effect on Staphylococcus aureus.

Human semen inhibited the growth of the 15 strains of Staph. aureus examined, the inhibition zone being larger on alkaline agar.

Spermine tetrahydrochloride, in concentrations of $100 \mathrm{mg} . \%$ and over, inhibited the growth of Staph. aureus on alkalinized media $(p \mathrm{H} 7.4)$ in 53 of 54 tests performed. Using the same medium and concentrations spermine phosphate inhibited the growth in all 21 tests performed. Spermine tetrahydrochloride, in concentrations up to $200 \mathrm{mg}$. \%, was active only if the medium was alkaline $(p \mathrm{H} \mathrm{7.4)}$. Spermine phosphate in that concentration was active both when the medium was alkaline $(p \mathrm{H} 7.4)$ and also, although to a lesser degree, when the medium had a $p \mathrm{H}$ of 6.8 . In this respect spermine phosphate resembles the plasma of human semen.

It is evident that the inhibition of the growth of Staph. aureus by human semen is due to its spermine content, though other substances which have not been examined may play a part.

We are indebted to B. Shapiro, Ph.D., and to E. Margoliash, M.D., for their helpful advice.

\section{REFERENCES}

Bichowsky-Slomnitzki, L. (1948). J. Bact., 55, 27.

Guggenheim, M. (1940). Die biogenen Amine, 3rd ed., pp. 211-241. Basel and New York.

Harrison, G. A. (1931). Biochem. J., 25, 1885.

(1933). Ibid., 27, 1152 .

Rozansky, R., Gurevitch, J., Brzezinsky, A., and Eckerling, B. (1949). J. Lab. clin. Med., 34, 1526. 